\title{
THE TWO FACES OF GALECTIN-3: ROLES IN VARIOUS PATHOLOGICAL CONDITIONS
}

Gordana D. Radosavljevic, Jelena Pantic, Ivan Jovanovic, Miodrag L. Lukic, Nebojsa Arsenijevic Centre for Molecular Medicine and Stem Cell Research, Faculty of Medical Sciences, University of Kragujevac, Serbia

\author{
DVA LICA GALEKTINA-3: \\ ULOGE U RAZLIČITIM PATOLOŠKIM STANJIMA \\ Gordana D. Radosavljević, Jelena Pantić, Ivan Jovanović, Miodrag L. Lukić, Nebojša Arsenijević \\ Centar za molekulsku medicinu i istraživanje matičnih ćelija, Fakultet medicinskih nauka, Univerzitet u Kragujevcu, Srbija
}

\section{ABSTRACT}

Galectin-3, a unique chimaera-type member of the lectin family, displays a wide range of activities. This versatile molecule is involved in fundamental biological processes, including cell proliferation, cell-cell adhesion, apoptosis and immune responses.

This review is aimed at providing a general overview of the biological actions and diverse effects of Galectin-3 in many pathological conditions, with a specific focus on autoimmunity, inflammation and tumour progression. We report herein that Galectin-3 exerts deleterious functions determined by promotion of tumour progression and liver inflammation or aggravation of $T$ cell-mediated autoimmune diseases. On the other hand, Galectin-3 exhibits a protective role in metabolic abnormalities and primary biliary cirrhosis.

The paradoxical "yin and yang" functions of Galectin-3 depend not only on its tissue and cellular localization but also on its availability, glycosylation status and the expression level of its ligands.

Keywords: galectin-3, tumour, inflammation, autoimmune disease

\section{INTRODUCTION}

Galectin-3 is one of the best-studied galectins. Like all members of the lectin family, Galectin-3 has a high affinity for binding $\beta$-galactoside and shares a conserved carbohydrate recognition domain (CRD) (1). As a chimeric protein with unique structure, Galectin-3 contains three distinct structural regions: 1 ) an $\mathrm{NH}_{2}$ terminus containing a serine phosphorylation site that is important for regulation of intracellular signalling; 2) a repetitive, prolinerich, collagen- $\alpha$-like sequence cleavable by matrix metalloproteases (e.g., MMP-2 and MMP-9); and 3) a globular $\mathrm{COOH}$-terminus containing a carbohydrate recognition domain and the anti-death motif NWGR. Upon binding

\section{SAŽETAK}

Galektin-3 je jedinstveni himerični član familije lektina $i$ ostvaruje širok spektar aktivnosti. Ovaj svestrani molekul je uključen u fundamentalne biološke procese kao što su ćelijska proliferacija, međućelijska adhezija, apoptoza $i$ imunski odgovor.

Pregledni članak ima za cilj opšti pregled bioloških efekata Galektina-3, kao i njegovih različitih uticaja na mnoga patološka stanja sa specifičnim fokusom na autoimunost, inflamaciju i progresiju tumoura. U ovom radu razmatrani su štetni efekti Galektina-3 koje ostvaruje u određenim patološkim stanjima: promovišs progresiju tumoura $i$ inflamaciju u jetri ili pogoršava neka autoimunska oboljenja izazvana T limfocitima. Suprotno, Galektin-3 igra protektivnu ulogu u patogenezi metaboličkih poremećaja i primarne bilijarne ciroze.

Paradoksne "Iin-Jang" funkcije Galektina-3 zavise od tkivne i ćelijske lokalizacije ovog molekula, a takođe i od dostupnosti, glikozilacionog statusa nivoa ekspresije njegovih liganada.

Ključne reči: galektin-3, tumour, inflamacija, autoimunske bolesti 
A

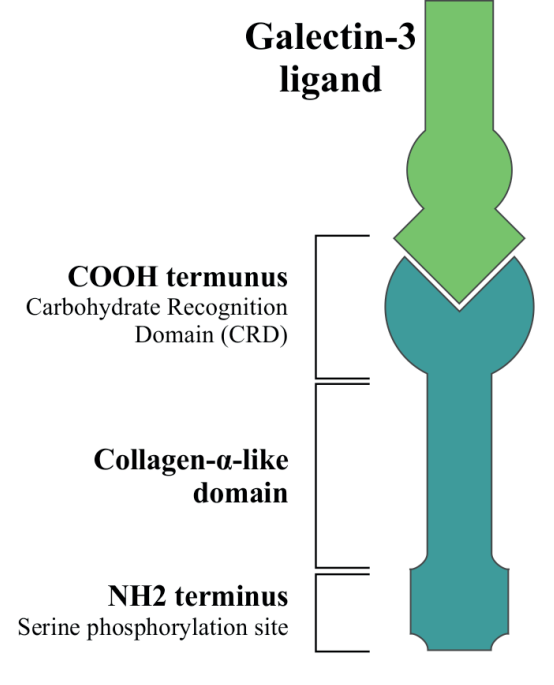

monomer

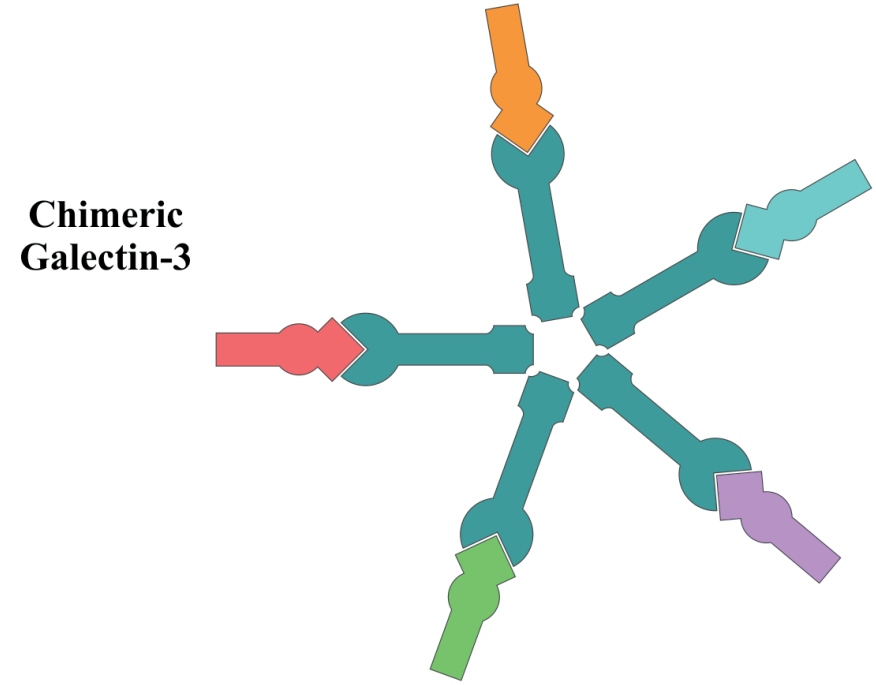

oligomer

B

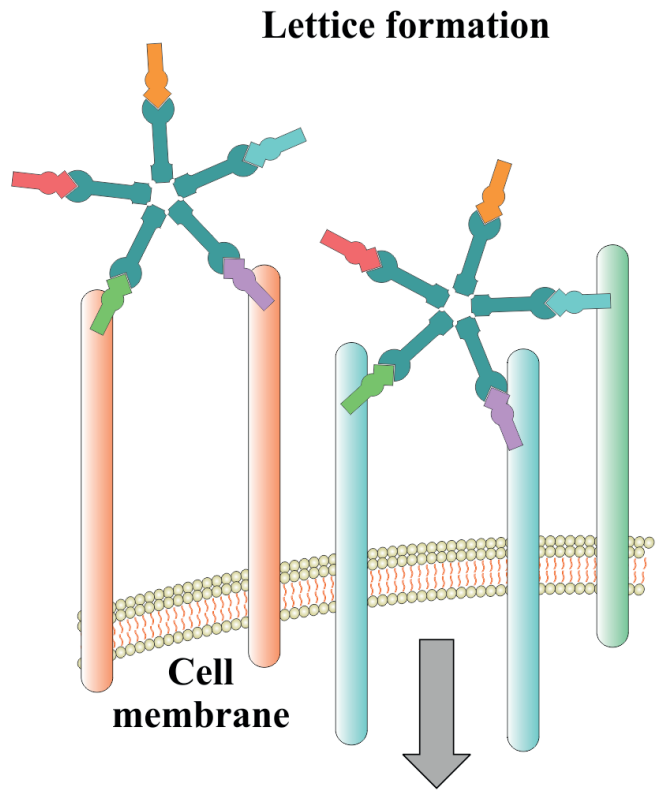

Signal transduction in the cells

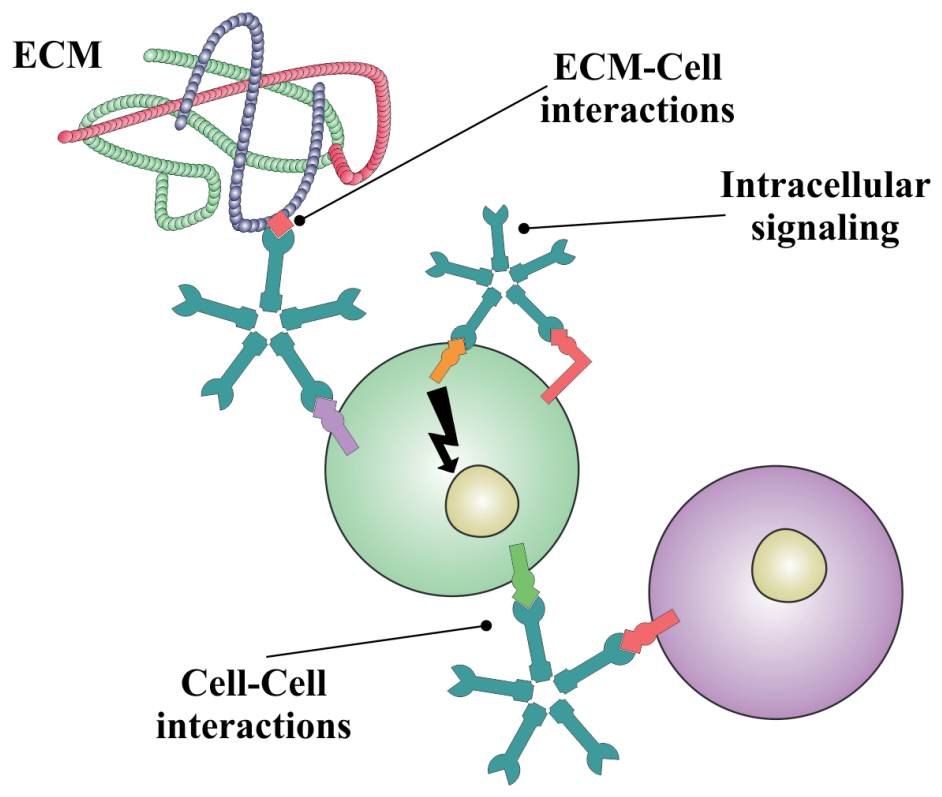

Figure 1. (A) Schematic representation of Galectin-3 monomer (left panel) and Galectin-3 oligomerization through its N-terminus in the presence of its binding ligands (right panel). (B) At the cell surface, Galectin-3 forms a pentameric lattice structure upon binding glycoproteins, thus participating in modulation of intracellular signalling pathways (left panel) as well as cell-cell and extracellular matrix (ECM)-cell interactions.

(3) and mitochondria $(4,5)$. Finally, it can be transported to the cell surface or secreted to the outside of cells. Galectin-3 interacts and co-operates with numerous intra- and extracellular ligands, thus participating in processes that are essential for basic cellular functions. For example, nuclear Galectin-3 acts as an mRNA splicing promoter and modulator of cell growth and proliferation $(1,6,7)$. How- ever, depending on its cellular localization, Galectin-3 may display dual effects, acting as both a negative and positive regulator of apoptosis. Cytoplasmic Galectin-3 functions as an apoptosis inhibitor by maintaining the membrane integrity of mitochondria. In contrast to cytoplasmic Galectin-3, it has been demonstrated that nuclear and extracellular Galectin-3 promote apoptosis (8-10). After bind- 
ing to cell surface molecules (e.g., CD29, CD7, CD95 and the T-cell receptor), extracellular Galectin-3 may mediate apoptosis, induced by cytochrome-c release and caspase- 3 activation (11-13).

Many reports suggest that extracellular Galectin-3 can act as a modulator of cellular adhesion. The multivalent characteristic of Galectin-3 enables it to act as a bridge between adjacent cells, as well as between cells and a plethora of extracellular matrix components $(1,14,15)$, by simultaneously binding to carbohydrates on two adhesion ligands (Figure 1B). These adhesive interactions between cells of the same and different types that occur by binding extracellular Galectin-3 allow Galectin-3 to promote homotypic and heterotypic aggregation, in particular in metastatic processes (15-17).

Galectin-3 is expressed on numerous immune cells and possesses several immunomodulating activities, such as promoting chemotaxis (18), inducing cell-cell adhesion (for instance, dendritic cell-T cell) and cell-matrix glycoprotein adhesion (19), regulating cell proliferation and survival $(8,20)$, and favouring superoxide production and phagocytosis by macrophages. It has been suggested that Galectin-3 also influences the strength of antigen activation in dendritic cells $(21,22)$ and controls acquired immunity, including both T-helper cell 1 (Th1) $(23,24)$ and T-helper cell 2 (Th2) responses $(21,25)$ depending on the context of the host immune response. Along with its role in inflammation and immune responses in noninfectious conditions, Galectin-3 can detect certain microorganisms by binding specific carbohydrate structures of glycoproteins and glycolipids from many pathogens (26). Recently, it has been reported that Galectin-3 acts as a novel alarmin by augmenting the inflammatory response in sepsis development during bacterial pneumonia following Francisella novicida infection (27). The alarmin properties of Galectin-3 include stimulation of an oxidative burst in neutrophils and inflammatory cytokine production in macrophages (27).

Taken together, these studies show that Galectin-3 is a versatile molecule that binds a plethora of intra- and extracellular ligands, thus activating different physiological processes inside and outside the cells. Further, Galectin-3 exerts diverse and sometimes opposing functions under various pathological conditions, depending on the specific tissue and cellular milieu. We will discuss how this molecule contributes to the immunopathology of different diseases, with a specific focus on autoimmunity, inflammation and tumour progression.

\section{GALECTIN-3 IN INFLAMMATION AND AUTOIMMUNITY}

Inflammation is generally protective and serves to maintain tissue homeostasis and repair. However, unbalanced inflammation becomes deleterious to the host and can lead to a variety of pathological conditions. For example, metabolic inflammation, referred to as metaflamma- tion, is a chronic inflammation generated from expanding adipose tissue and is induced by metabolic danger signals during obesity. Metaflammation precedes the development of metabolic abnormalities such as insulin resistance, type 2 diabetes and nonalcoholic fatty liver disease. Despite the fact that Galectin-3 exhibits deleterious effects under inflammatory conditions, various studies have demonstrated its protective role in the pathogenesis of obesity-induced inflammation triggered by accumulation of different metabolic stressors, such as advanced glycation end products (AGEs) (28). Namely, AGEs and the receptor for AGEs (RAGE) have been linked to enhanced apoptosis and dysfunction of pancreatic $\beta$ cells and also to the pathogenesis of diabetic complications (29). Galectin-3 has been identified as an AGE receptor (30) that binds AGEs with high affinity, thus acting as a scavenger receptor for these glucose adducts that are elevated in animals on a lipid-rich diet (29). Galectin-3 protects $\beta$ cells in rats from the cytotoxic effect of IL-1 $\beta$ (31). The expression levels of Galectin-3 in adipocytes and macrophages of adipose tissue and in serum are elevated during obesity in both humans and experimental animals (29).

To examine the role of Galectin-3 in obesity and type 2 diabetes, we used the model of high fat diet (HFD)induced obesity in Galectin-3-deficient mice (32). We showed that lack of Galectin-3 accelerates HFD-induced obesity and type 2 diabetes by increasing visceral adiposity, hyperglycaemia and insulin resistance and by upregulation of inflammatory pathways at both local (metabolic tissue) and systemic levels. Visceral adipose tissue of obese Galectin-3-deficient mice was infiltrated with type $1 \mathrm{CD}^{+}$ T lymphocytes, CD3 ${ }^{+} \mathrm{NK} 1.1^{+} \mathrm{NKT}$ lymphocytes expressing IFN- $\gamma$ and proinflammatory M1 macrophages, as well as $\mathrm{F} 4 / 80^{+} \mathrm{CD} 11 \mathrm{~b}^{+} \mathrm{CD} 11 \mathrm{c}^{+}$bone marrow-derived cells. In addition, regulatory $\mathrm{T}$ cells and, in particular, alternatively activated M2 macrophages were markedly reduced. These findings are complementary to a previous study demonstrating that Galectin-3 promotes M2-polarized macrophages (33). In addition to visceral adipose tissue, we found that a lack of Galectin-3 is also associated with inflammation in pancreatic islets, which is reflected by the presence of severe insulitis (32). This finding supports the concept that Galectin-3 has protective functions in metaflammation during obesity (29).

Principal mechanisms of obesity-induced inflammation include nuclear factor- $\mathrm{kB}(\mathrm{NF}-\mathrm{kB})$-dependent production of proinflammatory cytokines and increased activation of the NLRP3 (NOD-like receptor family, pyrin domain containing 3) inflammasome, leading to caspase1 -mediated cleavage and release of active proinflammatory IL-1 $\beta$ (34). In our study, increased expression of the NLRP3 inflammasome and IL-1 $\beta$ in macrophages was present in visceral adipose tissue and pancreatic islets of obese Galectin-3-deficient mice in comparison with wild type mice fed with an HFD (32). A key point of our work is that pancreatic islets of obese Galectin-3-deficient mice had increased deposition of AGE and RAGE expression, 
suggesting that deletion of the Galectin-3 gene impairs their removal, leading to accelerated inflammation and subsequent damage of pancreatic $\beta$-cells. Additionally, we noticed that this increased deposition of AGE and RAGE was accompanied by higher expression levels of phosphorylated NF-kB p 65 and mature caspase- 1 in pancreatic tissue and visceral adipose tissue (32). It appears that the NF- $\mathrm{B}$ B-mediated proinflammatory pathway operates in the enhanced metaflammation observed in Galectin-3-deficient mice.

Recently, it has been suggested that type 2 diabetes is an autoinflammatory disease with a central role for NLRP3-ASC (apoptosis-associated speck-like protein containing a caspase recruitment domain) inflammasome-mediated IL-1 $\beta$ production (35). In this regard, we noticed a trend towards increased expression of the NLRP3 inflammasome and ASC adaptor proteins in pancreatic and visceral adipose tissue, respectively. Additionally, peritoneal macrophages from Galectin-3-deficient mice released higher amounts of IL- $1 \beta$ and had increased NLRP3 inflammasome expression and caspase-1 activity in response to stimulation with lipopolysaccharide and/ or saturated fatty acid palmitate compared with peritoneal macrophages from wild type mice in vitro. We also noticed that silencing of the NLRP3 inflammasome attenuated IL-1 $\beta$ production by macrophages from Galectin-3-deficient mice, suggesting that the release of IL-1 $\beta$ was mediated by NLRP3 inflammasome activation. Finally, we demonstrated that obese Galectin-3-deficient mice had increased systemic inflammation, as shown by elevated serum levels of proinflammatory IL-6 and IL-1 $\beta$, followed by significantly decreased serum levels of immunomodulatory IL-13 and IL-10. Altogether, the results obtained from our study suggest an important protective role of Galectin-3 in obesity-induced inflammation and type 2 diabetes (32).

Nonalcoholic fatty liver disease (NAFLD) is a common chronic metabolic complication of obesity and type 2 diabetes (36). Liver steatosis is a benign condition that progresses to nonalcoholic steatohepatitis (NASH), which is characterized by chronic liver inflammation and fibrosis (37). The liver is the main catabolic site for AGEs and ALEs (advanced lipoxidation end-products) (38). Recently, it has been reported that Galectin-3 is involved in the regulation of fatty acid and glucose metabolism in the liver (39). RAGE, found predominantly in hepatocytes, and Galectin-3, which is highly expressed in sinusoidal liver endothelial and Kupffer cells, are the principal scavenger receptors for AGEs/ALEs and are involved in their removal without initiation of inflammation (40). To clarify the role of Galectin-3 in the pathogenesis of obesityrelated NASH, Galectin-3-deficient mice were placed on the obesogenic HFD (41). The data obtained show that Galectin-3 attenuates steatosis but promotes liver injury, inflammation and fibrosis, thus regulating disease progression in the obesogenic mouse model of NASH. In addition, we show here for the first time that the newly described profibrotic IL-33/ST2/IL-13 pathway in macrophages is Galectin-3-dependent (41).

The notion that Galectin-3 has a proinflammatory role in T-cell-mediated disease has been demonstrated in animal experimental models, such as Concanavalin A (Con A)-induced fulminant hepatitis (42). Con A is a potent, hepatotropic $\mathrm{T}$ cell mitogen, and it induces acute hepatitis in a model of $\mathrm{T}$ lymphocyte-mediated liver damage in mice (43). Our results demonstrate that ablation of Galectin-3 markedly attenuated liver injury by reducing the number of effector cells, such as $\mathrm{T}$ lymphocytes, natural killer (NK) and natural killer T (NKT) cells, and increasing the number of M2-polarized macrophages. Thus, our data support the assertion that Galectin-3 promotes inflammation in the liver following Con A injection. Further, apoptosis of liver-infiltrating cells contributes to the lower number of mononuclear cells in the livers of Galectin3-deficient mice, supporting the concept that Galectin-3 has an antiapoptotic role, particularly if it is localized within cells (42). Similar to the effects of deleting the Galectin-3 gene, pretreatment of wild type mice with a selective Galectin-3 inhibitor (TD139) also significantly reduced Con A-induced liver injury by suppressing infiltration of IFN- $\gamma^{-}$, IL-17- and IL-4-producing CD4+ $\mathrm{T}$ lymphocytes and IFN- $\gamma$-producing $\mathrm{CD}^{+}{ }^{+} \mathrm{T}$ lymphocytes, and increasing the number of IL-10-producing $\mathrm{CD}^{+} \mathrm{T}$ lymphocytes, as well as alternatively activated macrophages (42). Altogether, our findings indicated that reduced inflammation in the liver of Con A-treated Galectin-3-deficient mice and TD139-pretreated wild type mice could be the result of attenuation of macrophage and T cell activity.

Primary biliary cirrhosis (PBC) is considered a progressive autoimmune liver disease with immune-mediated destruction of intrahepatic biliary epithelial cells and frequent appearances of autoantibodies against the major mitochondrial autoantigen, PDC-E2 (pyruvate dehydrogenase complex component E2) $(44,45)$. It appears that biliary epithelial cells (BECs) are the major targets of injury and thus they are active participants in the initiation and perpetuation of autoimmunity in the pathogenesis of $\mathrm{PBC}$. It is assumed that a unique apoptotic feature of biliary epithelial cells may contribute to epitope presentation to the immune system, causing unique tissue damage $(46,47)$. In this scenario, both acquired and innate immunity have been proposed as contributors in autoimmune-mediated destruction (48).

Our laboratory has decided to examine the role of Galectin-3 in PBC pathogenesis by using a murine model of autoimmune cholangitis following immunization of Galectin-3-deficient mice with 2-octynoic acid (2OA) coupled to BSA (2OA-BSA). In contrast to the results from our previous studies, which indicated that deletion of the Galectin-3 gene reduces several T cell-mediated autoimmune diseases, such as diabetes (49) and experimental autoimmune encephalomyelitis (50), we demonstrate here that another autoimmune disease, $\mathrm{PBC}$, is aggravated by Galectin-3 deficiency (data have been accepted for pub- 
lication). This autoimmune disease is characterized by increased periportal infiltration, bile duct damage, granulomas and fibrosis. It is well established that intracellular Galectin-3 is a critical negative regulator of apoptosis. Thus, the cause of these differences appears to be the fact that in PBC, the ablation of Galectin-3 leads to increased availability of autoantigen(s). In actuality, lack of Galectin-3 may affect mitochondrial membrane integrity and resistance to apoptosis in BECs and, consequently, cause the release of putative antigen(s) that induce a stronger activation of DCs, a higher influx of inflammatory lymphocytes, and enhanced bile duct damage and liver fibrosis. In addition, we did not detect Galectin-3 expression in BECs from healthy wild type mice. However, the expression of Galectin-3 was significantly increased in BECs from 2OA-BSA-immunized mice. Finally, we assume that increased expression of Galectin-3 in BECs in the murine model of autoimmune cholangitis is probably a compensatory mechanism that is used to protect the BECs from apoptosis induced by different stimuli.

\section{PROTUMOURIGENIC ROLE OF GALECTIN-3}

Galectin-3 expression is altered or abnormally localized in cells of various human solid tumours and blood malignancies, suggesting that this multifunctional molecule may modulate tumour progression and influence disease outcome $(1,51)$. Some immunohistochemistry studies have indicated that overexpression of Galectin-3 may be a prognostic factor for poor survival of patients with gastric cancer, hepatocellular carcinoma, thyroid cancer and leukaemia (52-56). It seems that the translocation of Galectin-3 from the cytoplasm to the nucleus of melanoma cells results in a more aggressive phenotype (57). Interestingly, tumour hypoxia upregulates the expression of Galectin-3 and also leads to changes in its subcellular localization (58). Under hypoxic conditions, the expression of Galectin-3 shifts from a nuclear location to cytoplasmic and membranous locations, suggesting that this shift favours resistance to apoptosis and malignancy of mammary tumour cells (58). Circulating Galectin-3 is also increased in the bloodstream of cancer patients. Thus, markedly higher serum concentrations of Galectin-3 were found among patients with many types of cancer (59-61), compared with those of healthy individuals. Additionally, patients with advanced melanoma have higher concentrations of circulating Galectin-3 than those with localized tumours. It appears that the source of increased Galectin-3 concentrations in the serum of patients with cancer may be the tumour cells, as well as the peritumoural inflammatory and stromal cells $(16,59)$.

Despite its involvement in physiological processes, $\mathrm{Ga}$ lectin-3 is also a key player in many steps of tumour development and metastasis. It has been demonstrated that Galectin-3 favours a broad range of cancer cell activities, such as malignant cell transformation and tumour growth
(62-64), cell adhesion, migration and invasion (65-69), anoikis resistance (70), apoptosis inhibition (71), (72) and angiogenesis (73).

Galectin-3 can promote malignant transformation due to simultaneous stimulation of cell growth and prevention of apoptosis. For example, nuclear Galectin-3 can interact with $\beta$-catenin to enhance the expression of cyclin D and c-Myc (74) and thus promote cell cycle progression (14). This galectin can upregulate $\beta$-catenin expression in the nucleus of human colon cancer cells and augment Wnt/ $\beta$ catenin signalling by regulating glycogen synthase kinase$3 \beta$ (GSK-3 $\beta$ ) phosphorylation and activity via the PI3K/ Akt pathway (75). Additionally, cytoplasmic Galectin-3 may cause constitutive activation of Ras-dependent PI3K and Raf- 1 activation by its interaction with activated K-Ras (63). Altogether, these results suggest that Galectin-3 is a pivotal player in the regulation of cancer-related gene expression and the activation of many signalling pathways. One of the main hallmarks of cancer is the evasion of apoptosis that contributes to cancer cells' survival. An additional function of Galectin-3 that is relevant to tumour progression is inhibition of apoptosis. Following apoptotic stimuli, Galectin-3 translocates from either the cytosol or the nucleus to the mitochondria (4), where it interacts with Bcl-2 and blocks the alteration of mitochondrial membrane potential and cytochrome-c release (71). It has also been reported that Galectin-3 heterodimerizes with Bax, mediated by the carbohydrate recognition domain of Galectin-3, which leads to attenuation of apoptosis in human thyroid carcinoma cells (76). Further, this galectin is an important antiapoptotic effector molecule that confers resistance to conventional cancer chemotherapy. Thus, when leukaemia cells were treated with cisplatin, Galectin-3 expression was upregulated and caused resistance to apoptosis in surviving cells (77). In contrast, silencing of Galectin-3 in gastric cancer cells augments apoptosis induction by chemotherapy by decreasing the expression of cell survival molecules (e.g., survivin and cyclin D1) (78). Additionally, the silencing of Galectin-3 with RNA interference also sensitizes multidrug-resistant cells to epirubicin by activation of the mitochondrial apoptosis pathway through modulation of the $\beta$-catenin/GSK-3 $\beta$ pathway in human colon cancer cells (79).

The migratory and invasive potential of tumour cells is associated with tumour progression. The invasion and metastasis processes involve changes in several proteins engaged in cell-cell and cell-matrix adhesion (2), and cell surface expression of Galectin-3 seems to contribute to these processes, thus promoting the metastatic spread of cancer cells from primary to secondary tumour sites $(51,80)$. Adhesive interaction with components of the extracellular matrix (ECM) is important for migration of malignant cells (81). It is well established that Galectin-3 interacts with glycoproteins of the ECM, such as fibronectin, collagen IV, elastin and laminin $(19,82)$. It appears that increased levels of Galectin-3 in the bloodstream of cancer patients can be critical in malignant cell metastasis 
(16). One of the Galectin-3 binding partners is oncofoetal Thomsen-Friedenreich antigen, which is on the transmembrane mucin protein MUC1 expressed by many metastatic cells (83). This interaction results in increased tumour cell homotypic aggregation to form microtumour emboli that prolong metastatic cell survival in the circulation by prevention of anoikis and enhanced heterotypic adhesion of the metastatic cells to the vascular endothelium (83-85).

A critical step in successful establishment of organspecific metastasis is the adhesion interactions of tumour cells with the host microenvironment, especially interactions with components of the ECM and vascular endothelium in target organs. It appears that the degree of organ-specific metastasis may be associated with Galectin-3 expression in the lungs. In this regard, we reported that Galectin-3 ablation in the host markedly decreases lung melanoma metastasis. In an experimental model of B16-F1 murine melanoma, we demonstrated that Galectin-3-deficient mice were more resistant to metastatic melanoma, as evidenced by markedly reduced number and size of lung metastatic colonies compared with wild type mice. In addition, by in vitro assay we noticed lower numbers of attached malignant cells in lung tissue sections of Galectin-3-deficient mice, suggesting that hostderived Galectin-3 plays a pivotal role in tumour cell adhesion to the metastatic target (86). Recently, it has been shown that Galectin-3, which is expressed in lungs (especially on the vascular endothelium), cooperates with poly-N-acetyl-lactosamine on N-glycans on B16-F1 murine melanoma cells, as a ligand for Galectin-3 (87). This interaction between Galectin-3 and its glycoprotein ligand not only facilitates initial adhesion of tumour cells to the vascular endothelium but also participates in subsequent metastatic processes such as extravasation, degradation of the matrix and organ colonization (88). Finally, metastatic cells continue to proliferate in the target organ. Tumour angiogenesis is involved in the metastatic cascade both at the primary site and at downstream sites of metastasis. In addition to its role in dissemination of tumour cells, angiogenesis is also required for expansion of the metastatic colony in the target tissue. It appears that Galectin-3 has proangiogenic activity via interactions with several endothelial cell surface receptors. For example, Galectin-3 interacts with $\alpha v \beta 3$ integrin on endothelial cells and induces promotion of VEGF- and bFGF-mediated endothelial migration and, consequently, vessel branch formation (89).

Immune evasion and suppression are associated with tumour progression through inhibition of effector immune cells or via expansion of immunosuppressive cells $(90,91)$. Galectin-3 is an important modulator of immune responses through the regulation of homeostasis and immune cell function. For example, Galectin-3 reduces the affinity of the T-cell receptor (TCR) for major histocompatibility complex (MHC) Class I and peptide ligand by segregating the TCR from its CD8 coreceptor (92), disrupts the immunological synapse by internalizing the TCR (93), and induces apoptosis of $\mathrm{T}$ cells (94).
It is well established that NK cells and $\mathrm{CD}^{+}$cytotoxic $\mathrm{T}$ cells are crucial players in the control of melanoma growth and metastasis. Recently, Kouo et al. (95) suggested that Galectin-3 modulates antitumour immune responses by suppressing effector $\mathrm{CD} 8^{+} \mathrm{T}$ cells exclusively in the tumour microenvironment via lymphocyte activation gene 3 (LAG-3), an inhibitory receptor that is associated with regulation of terminal T-cell activation/exhaustion. Our data support a link between Galectin-3 and the cytotoxic capacity of NK cells, but not that of $\mathrm{CD}^{+} \mathrm{T}$ cells. In fact, we demonstrated that lack of Galectin-3 is associated with enhanced tumouricidal activity of NK cells directed against B16-F1 melanoma cells (86). The antitumour capacity of NK cells is dependent on their development and maturation. We observed that Galectin-3-deficient mice constitutively have a significantly higher percentage of effective cytotoxic $\mathrm{CD} 27^{\text {high }} \mathrm{CD} 11 \mathrm{~b}^{\text {high }} \mathrm{NK}$ cells and immature CD$27^{\text {high }} \mathrm{CD} 11 \mathrm{~b}^{\text {low }} \mathrm{NK}$ cells, regardless of reduced numbers of NK1.1 $1^{+}$cells in the spleen, compared with wild type mice. However, the percentage of less functionally exhausted CD2 $7^{\text {low }} \mathrm{CD} 11 \mathrm{~b}^{\text {high }} \mathrm{NK}$ cells and NK cells bearing the inhibitory KLRG1 receptor was markedly lower in Galectin-3-deficient mice (86). It is believed that Galectin-3 interferes with binding to regulatory molecules on the cancer cell that serve as ligands for receptors of NK cells (96). Additionally, the results from Wang et al. (97) suggested that expression of membrane KLRG1 receptors on NK cells impairs their activation and IFN- $\gamma$ production, but increases apoptosis of these cells in chronic hepatitis $C$ virus infection.

Some evidence suggested that Galectin-3 is associated with a decrease in regulatory $\mathrm{T}$ (Treg) cell frequency and thus influences the course of experimental autoimmune encephalomyelitis and Leishmania major infection (98, 99). These results raise the question of whether Galectin-3 deficiency also impaired the number of Treg cells in an experimental model of B16-F1 murine melanoma. We noticed that injection of melanoma cells resulted in marked increases in the percentage and total number of regulatory $\mathrm{CD}^{+}{ }^{+} \mathrm{Foxp}^{+} \mathrm{T}$ cells in wild type mice, but not in Galectin3-deficient mice (86). Thus, our findings suggest that hostderived Galectin-3 could lead to an increase in the number and percentage of Treg cells, which promotes the formation of an immunosuppressive tumour network and can be one of the main facilitative mechanisms important for tumour metastasis. A high number of Treg cells has been directly correlated to cancer progression (100). In our experimental model of B16-F1 murine melanoma, it appears that the most important role of Treg cells is suppression of NK cell function. A previous study demonstrated that a high number of Treg cells was inversely correlated to the frequency and function of NK cells (100). For example, cocultivation of human allogeneic Treg cells with resting NK cells led to markedly reduced NK cell natural cytotoxicity, cytokine production and expression of NKG2D activating receptors in vitro (101). 


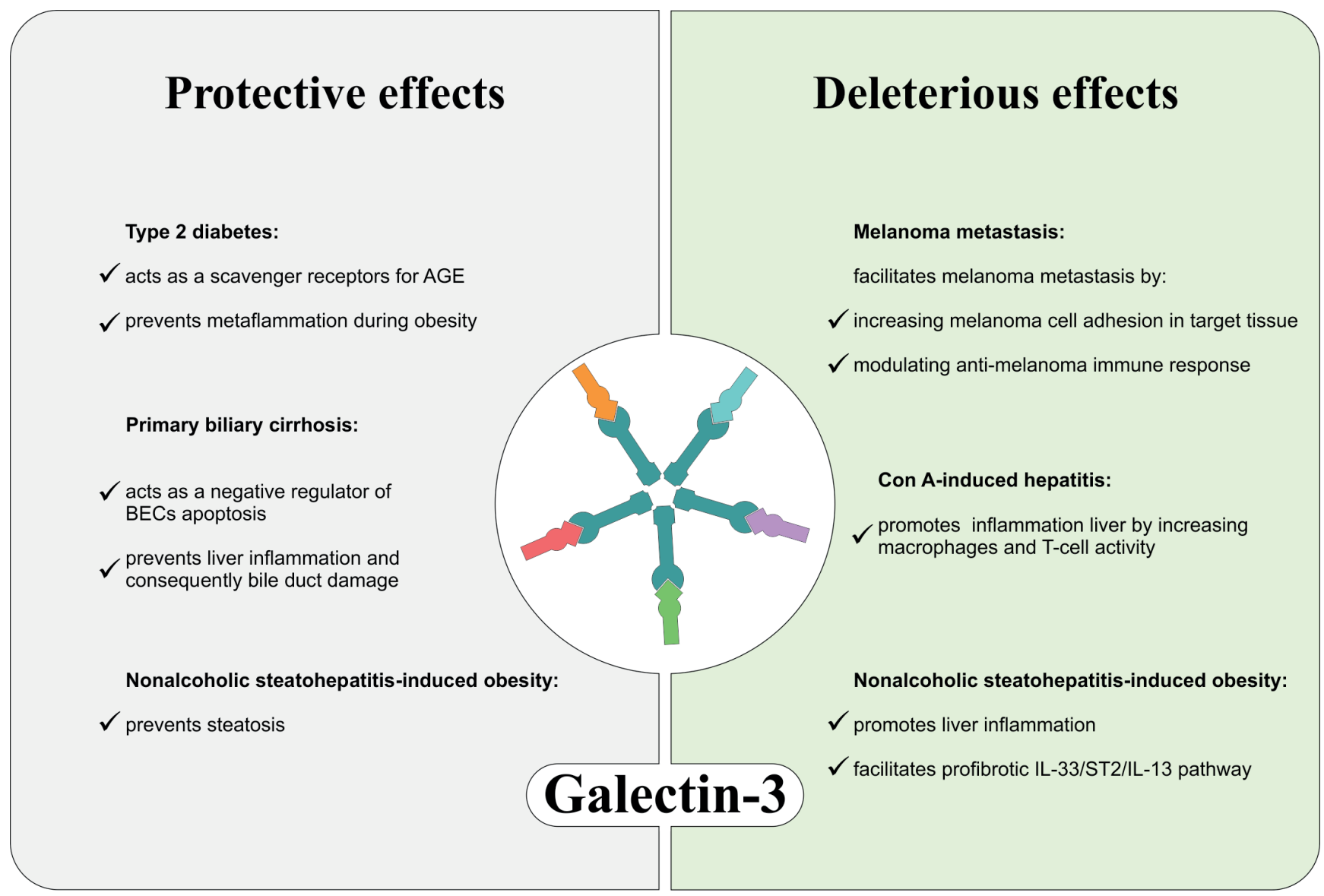

Figure 2. The effects of Galectin-3 in inflammation, autoimmunity and melanoma metastasis.

While IL-17 exhibited both protumour and antitumour roles (102), IFN- $\gamma$ exerted potent antitumour immunity against melanoma and various other cancers (103). It has been reported that IFN- $\gamma$ has direct antiproliferative and proapoptotic effects on tumour cells in animal models $(104,105)$ and that these effects prevent B16 experimental metastasis by directly inhibiting cell growth (106). We observed higher serum levels of IFN- $\gamma$ and IL-17 in tumour-bearing hosts in Galectin-3 deficiency, which was not accompanied by differences in the number of $\mathrm{CD}^{+}$ and $\mathrm{CD} 8^{+} \mathrm{T}$ cells in the spleen. This does not exclude the possibility that the number of tumour-specific Th1 cells and cytotoxic $\mathrm{CD}^{+} \mathrm{T}$ cells is different (86). Reported data suggest that Galectin-3 suppresses IFN- $\gamma$ production by antigen-specific $\mathrm{CD} 8^{+} \mathrm{T}$ cells in vitro (95). Further, dendritic cells lacking the Galectin-3 gene have been shown to increase both T-cell numbers and cytokine production in helminthic infections and promote an effective Th17 immune response $(107,108)$. Altogether, it appears that Galectin-3 is involved in the tuning of acquired immunity against tumours by determining the cytokine milieu in the tumour microenvironment.

In summary, our data determined several findings supporting Galectin-3 as a potential facilitator of melanoma lung metastasis. First, host-derived Galectin-3 is a critical player in tumour cell adhesion to the metastatic target and thus contributes to the initial adhesion and survival of circulating metastatic cells. Second, Galectin-3 shapes the immune response against B16-F1 melanoma cells by suppressing effector NK cells and enhancing expansion of $\mathrm{CD}^{+}{ }^{+} \mathrm{Foxp}^{+} \mathrm{T}$ cells. Thus, our findings clearly confirm the results obtained in other studies suggesting that Galectin-3 has a wide range of pivotal protumourigenic functions that are associated with tumour growth and metastasis, implying that it would be an ideal therapeutic target to prevent tumour progression.

\section{EXPERT OPINION}

The cell- and tissue-specific profiles of Galectin-3 expression differ under physiological and pathological conditions $(14,109,110)$; they can undergo a variety of changes under the stress conditions encountered in tumour microenvironments, inflammation or fibrosis. Divergent specificities and affinities of Galectin-3 for various glycoproteins appear to contribute to the multiplicity of its activities.

Galectin-3 is a highly versatile protein and a potent modulator of pivotal cellular processes. The role of Galectin-3 in various pathological conditions is complex, with diverse and sometimes opposing functions. We report 
herein that Galectin-3 exhibits deleterious roles in the promotion of tumour progression and liver inflammation after Con A injection and the aggravation of $\mathrm{T}$ cell-mediated autoimmune diseases such as type 1 diabetes and experimental autoimmune encephalomyelitis. However, it appears that Galectin-3 has a protective function in conditions such as type 2 diabetes and primary biliary cirrhosis. In addition, the paradoxical role of Galectin-3 in nonalcoholic steatohepatitis during obesity is reflected in the fact that it contributes to inflammation and fibrosis in the liver, but reduces steatosis (as illustrated in Figure 2). The functional dichotomy in various pathological conditions suggests that the effects of Galectin-3 depend on cellular and tissue localization, or the availability, glycosylation status or expression level of its ligands.

The key question is: How does Galectin-3 achieve its target specificity to become a meaningful effective molecule? The identification and characterization of the nature and structural diversity of Galectin-3 ligand(s) (e.g., glycoconjugate or protein) responsible for target selectivity (111) will be the basis for not only developing rational antiinflammatory and antitumoural approaches but also for taking advantage of the protective functions of Galectin-3 in metabolic abnormalities or primary biliary cirrhosis. Specifically, the major aim for therapeutic manipulation is singling out the pathological aspect in target tissue while avoiding harm at the physiologic site. Ideally, Galectin-3 therapy should be strictly spatially confined.

\section{Acknowledgements and Funding:}

We thank Milan Milojevic for excellent technical assistance. This work was funded by grants from the Ministry of Education, Science and Technological Development, Serbia (Grants ON 175071, ON 175069 and ON 175103) and from the Faculty of Medical Sciences of the University of Kragujevac, Serbia (Grants MP 02/14 and MP 01/14).

\section{REFERENCES:}

1. Liu FT, Rabinovich GA. (2005). Galectins as modulators of tumour progression. Nat Rev Cancer, 5(1), 29-41.

2. Radosavljevic G, Volarevic V, Jovanovic I, Milovanovic M, Pejnovic N, Arsenijevic N, et al. (2012). The roles of Galectin-3 in autoimmunity and tumor progression. Immunol Res, 52,100-110.

3. Moutsatsos IK, Wade M, Schindler M, Wang JL. (1987). Endogenous lectins from cultured cells: nuclear localization of carbohydrate binding protein 35 in proliferating 3T3 fibroblasts. Proc Natl Acad Sci USA, 84, 6452-6456.

4. Yu F, Finley R, Raz A, Kim H-RC. (2002). Galectin-3 translocates to the perinuclear membranes and inhibits cytochrome c release from the mitochondria. A role for synexin in galectin-3 translocation. J Biol Chem, 277(18), 15819-15827.
5. Paron I, Scaloni A, Pines A, Bachi A, Liu F-T, Puppin C, et al. (2003). Nuclear localization of Galectin-3 in transformed thyroid cells:a role in transcriptional regulation. Biochem Biophys Res Commun, 302(3), 545-553.

6. Dagher SF, Wang JL, Patterson RJ. (1995). Identification of galectin-3 as a factor in pre-mRNA splicing. Proc Natl Acad Sci USA, 92(4), 1213-1217.

7. Wang JL, Gray RM, Haudek KC, Patterson RJ. (2004). Nucleocytoplasmic lectins. Biochim Biophys Acta, 1673(1-2), 75-93.

8. Yang RY, Hsu DK, Liu FT. (1996). Expression of galectin-3 modulates T-cell growth and apoptosis. Proc Natl Acad Sci USA, 93, 6737-6742.

9. Califice S, Castronovo V, Bracke M, van den Brûle F. (2004). Dual activities of galectin-3 in human prostate cancer: tumor suppression of nuclear galectin-3 vs tumor promotion of cytoplasmic galectin-3. Oncogene, 23(45), 7527-7536.

10. Nakahara S, Oka N, Raz A. (2005). On the role of galectin-3 in cancer apoptosis. Apoptosis, 10(2), 267-275.

11. Scaffidi C, Fulda S, Srinivasan A, Friesen C, Li F, Tomaselli KJ, et al. (1998). Two CD95 (APO-1/Fas) signaling pathways. EMBO J, 17(6), 1675-1687.

12. Fukumori T, Takenaka Y, Oka N, Yoshii T, Hogan V, Inohara $\mathrm{H}$, et al. (2004). Endogenous galectin-3 determines the routing of CD95 apoptotic signaling pathways. Cancer Res, 64(10), 3376-3379.

13. Hsu DK, Chen HY, Liu FT. (2009). Galectin-3 regulates T-cell functions. Immunol Rev, 230(1), 114-127.

14. Dumic J, Dabelic S, Flögel M. (2006). Galectin-3: an openended story. Biochim Biophys Acta, 1760, 616-635.

15. Funasaka T, Raz A, Nangia-Makker P. (2014). Galectin-3 in angiogenesis and metastasis. Glycobiology, 24(10), 886-891.

16. Yu L-G. (2010). Circulating galectin-3 in the bloodstream: An emerging promoter of cancer metastasis. World J Gastrointest Oncol, 2(4), 177-180.

17. Braeuer RR, Shoshan E, Kamiya T, Bar-Eli M. (2012). The sweet and bitter sides of galectins in melanoma progression. Pigment Cell Melanoma Res, 25(5), 592-601.

18. Sano H, Hsu DK, Yu L, Apgar JR, Kuwabara I, Yamanaka T, et al. (2000). Human galectin-3 is a novel chemoattractant for monocytes and macrophages. J Immunol, 165, 2156-2164.

19. Ochieng J, Leite-Browning ML, Warfield P. (1998). Regulation of cellular adhesion to extracellular matrix proteins by galectin-3. Biochem Biophys Res Commun, 246, 788-791.

20. Demetriou M, Granovsky M, Quaggin S, Dennis JW. (2001). Negative regulation of T-cell activation and autoimmunity by Mgat5 N-glycosylation. Nature, 409, 733-739.

21. Breuilh L, Vanhoutte F, Fontaine J, van Stijn CM, TillieLeblond I, Capron M, et al. (2007). Galectin-3 modulates immune and inflammatory responses during helminthic infection: impact of galectin-3 deficiency on the functions of dendritic cells. Infect Immun, 75, 5148-5157. 
22. Wu SY, Yu JS, Liu FT, Miaw SC, Wu-Hsieh BA. (2013). Galectin-3 negatively regulates dendritic cell production of IL-23/IL-17-axis cytokines in infection by Histoplasma capsulatum. J Immunol, 190, 3427-3437.

23. Cortegano I, del Pozo V, Cárdaba B, de Andrés B, Gallardo S, del Amo A et al. (1998). Galectin-3 down-regulates IL-5 gene expression on different cell types. J Immunol, 161, 385-389.

24. Ruas LP, Bernardes ES, Fermino ML, de Oliveira LL, Hsu DK, Liu FT. et al. (2009). Lack of galectin-3 drives response to Paracoccidioides brasiliensis toward a Th2-biased immunity. PLoS One, 4, e4519.

25. Bernardes ES, Silva NM, Ruas LP, Mineo JR, Loyola AM, Hsu DK, et al. (2006). Toxoplasma gondii infection reveals a novel regulatory role for galectin- 3 in the interface of innate and adaptive immunity. Am J Pathol, 168, 1910-1920.

26. Ochieng J, Furtak V, Lukyanov P. (2004). Extracellular functions of galectin-3. Glycoconj J, 19, 527-535.

27. Mishra BB, Li Q, Steichen AL, Binstock BJ, Metzger DW, Teale JM, et al. (2013). Galectin-3 functions as an alarmin: pathogenic role for sepsis development in murine respiratory tularemia. PLoS One, 8(3), e59616.

28. Iacobini C, Menini S, Oddi G, Ricci C, Amadio L, Pricci F, et al. (2004). Galectin-3/AGE-receptor 3 knockout mice show accelerated AGE-induced glomerular injury: evidence for a protective role of galectin-3 as an AGE receptor. FASEB Journal, 18, 1773-1775.

29. Pejnovic NN, Pantic JM, Jovanovic IP, Radosavljevic GD, Djukic ALj, Arsenijevic NN, et al. (2013). Galectin-3 is a regulator of metaflammation in adipose tissue and pancreatic islets. Adipocyte, 2(4), 266-271.

30. Vlassara H, Li YM, Imani F, Wojciechowicz D, Yang Z, Liu FT et al. (1995). Identification of galectin-3 as a high-affinity binding protein for advanced glycation end products (AGE): a new member of the AGE-receptor complex. Mol Med, 1, 634-646.

31. Karlsen AE, Størling ZM, Sparre T, Larsen MR, Mahmood A, Størling J, et al. (2006). Immune-mediated betacell destruction in vitro and in vivo-A pivotal role for galectin-3. Biochem Biophys Res Commun, 344, 406-415.

32. Pejnovic NN, Pantic JM, Jovanovic IP, Radosavljevic GD, Milovanovic MZ, Nikolic IG, et al. (2013). Galectin-3 deficiency accelerates high-fat diet-induced obesity and amplifies inflammation in adipose tissue and pancreatic islets. Diabetes, 62(6), 1932-1944.

33. MacKinnon AC, Farnworth SL, Hodkinson PS, Henderson NC, Atkinson KM, Leffler H, et al. (2008). Regulation of alternative macrophage activation by galectin-3. J Immunol, 180, 2650-2658.

34. Zhou R, Tardivel A, Thorens B, Choi I, Tschopp J. (2010). Thioredoxin-interacting protein links oxidative stress to inflammasome activation. Nat Immunol, 11, 136-140.

35. Vandanmagsar B, Youm YH, Ravussin A, Galgani JE, Stadler K, Mynatt RL, et al. (2011). The NLRP3 inflammasome instigates obesity-induced inflammation and insulin resistance. Nat Med, 17,179-188.
36. Angulo P. (2007). Obesity and nonalcoholic fatty liver disease. Nutr Rev, 65, S57-S63.

37. Chalasani N, Younossi Z, Lavine JE, Diehl AM, Brunt EM, Cusi K, et al. (2012). The diagnosis and management of non-alcoholic fatty liver disease: Practice guideline by the american associations for the study of liver diseases, American college of gastroenterology, and the American gastroenterologycal association. Hepatology, 55(6), 2005-2023.

38. Pugliese G, Iacobini C, Pesce CM, Menini S. (2015). Galectin-3: an emerging all-out player in metabolic disorders and their complications. Glycobiology, 25(2), 136-150.

39. Rhodes DH, Pini M, Castellanos KJ, Montero-Melendez T, Cooper D, Perretti M, et al. (2013). Adipose tissue specific modulation of galectin expression in lean and obese mice: Evidence for regulatory function. Obesity (Silver Spring), 21, 310 -319.

40. Butscheid M, Hauptvogel P, Fritz P, Klotz U, Alscher D. (2007). Hepatic expression of Galectin-3 and RAGE in patients with liver disease. J Clin Pathol, 60, 415-418.

41. Jeftic I, Jovicic N, Pantic J, Arsenijevic N, Lukic ML, Pejnovic N. (2015). Galectin-3 Ablation Enhances Liver Steatosis, but Attenuates Inflammation and IL-33-Dependent Fibrosis in Obesogenic Mouse Model of Nonalcoholic Steatohepatitis. Mol Med, 21, 453-465.

42. Volarevic V, Milovanovic M, Ljujic B, Pejnovic N, Arsenijevic N, Nilsson U, et al. (2012). Galectin-3 deficiency prevents concanavalin A-induced hepatitis in mice. Hepatology, 55(6), 1954-1964.

43. Tiegs G, Hentschel J, Wendel A. (1992). A T cell-dependent experimental liver injury in mice inducible by concanavalin A. J Clin Invest, 90(1), 196-203.

44. Kaplan MM, Gershwin ME. (2005). Primary biliary cirrhosis. The New England Journal of Medicine, 353(12), 1261-1273.

45. Gershwin ME, Mackay IR. (2008). The causes of primary biliary cirrhosis: Convenient and inconvenient truths. Hepatology, 47(2), 737-745.

46. Chuang YH, Lan RY, Gershwin ME. (2009). The immunopathology of human biliary cell epithelium. Semin Immunopathol, 31,323-331.

47. Kimura Y, Leung PS, Kenny TP, Van De Water J, Nishioka M, Giraud AS, et al. (2002). Differential expression of intestinal trefoil factor in biliary epithelial cells of primary biliary cirrhosis. Hepatology, 36(5), 1227-1235.

48. Sasaki M, Nakanuma Y. (2010). Biliary Epithelial Apoptosis, Autophagy, and Senescence in Primary Biliary Cirrhosis. Hepatitis Research and Treatment, 2010, 205128.

49. Mensah-Brown EP, Al Rabesi Z, Shahin A, Al Shamsi M, Arsenijevic N, Hsu DK, et al. (2009). Targeted disruption of the galectin-3 gene results in decreased susceptibility to multiple low dose streptozotocin-induced diabetes in mice. Clin Immunol, 130, 83-88. 
50. Jiang HR, Al Rasebi Z, Mensah-Brown E, Shahin A, Xu D, Goodyear CS, et al. (2009). Galectin-3 deficiency reduces the severity of experimental autoimmune encephalomyelitis. J Immunol, 182, 1167-1173.

51. Takenaka Y, Fukumori T, Raz A. (2004). Galectin-3 and metastasis. Glycoconj J, 19, 543-549.

52. Miyazaki J, Hokari R, Kato S, Tsuzuki Y, Kawaguchi A, Nagao S, et al. (2002). Increased expression of galectin-3 in primary gastric cancer and the metastatic lymph nodes. Oncol Rep, 9(6), 1307-1312.

53. Jiang S-S, Weng D-S, Wang Q-J, Pan Ke, Zhang Y-J, Li Y-Q, et al. (2014). Galectin-3 is associated with a poor prognosis in primary hepatocellular carcinoma. J Transl Med, 12, 273.

54. Thijssen VL, Heusschen R, Caers J, Griffioen AW. (2015). Galectin expression in cancer diagnosis and prognosis: a systematic review. Biochim Biophys Acta, 1855, 235-247.

55. Chiu CG, Strugnell SS, Griffith OL, Jones SJ, Gown AM, Walker B, et al. (2010). Diagnostic utility of galectin-3 in thyroid cancer. Am J Pathol, 176, 2067-2081.

56. Cheng CL, Hou HA, Lee MC, Liu CY, Jhuang JY, Lai YJ, et al. (2013). Higher bone marrow LGALS3 expression is an independent unfavorable prognostic factor for overall survival in patients with acute myeloid leukemia. Blood, 121, 3172-3180.

57. Prieto VG, Mourad-Zeidan AA, Melnikova V, Johnson MM, Lopez A, Diwan AH, et al. (2006). Galectin-3 expression is associated with tumor progression and pattern of sun exposure in melanoma. Clin Cancer Res, 12(22), 6709-6715.

58. de Oliveira JT, Ribeiro C, Barros R, Gomes C, de Matos AJ, Reis CA, et al. (2015). Hypoxia Up-Regulates Galectin-3 in Mammary Tumor Progression and Metastasis. PLoS One, 10(7), e0134458.

59. Iurisci I, Tinari N, Natoli C, Angelucci D, Cianchetti E, Iacobelli S. (2000). Concentrations of galectin-3 in the sera of normal controls and cancer patients. Clin Cancer Res, 6, 1389-1393.

60. Saussez S, Lorfevre F, Lequeux T, Laurent G, Chantrain G, Vertongen F, et al. (2008). The determination of the levels of circulating galectin-1 and - 3 in HNSCC patients could be used to monitor tumor progression and/or responses to therapy. Oral Oncol, 44, 86-93.

61. Vereecken P, Zouaoui Boudjeltia K, Debray C, Awada A, Legssyer I, Sales F, et al. (2006). High serum galectin-3 in advanced melanoma: preliminary results. Clin Exp Dermatol, 31, 105-109.

62. Takenaka Y, Inohara H, Yoshii T, Oshima K, Nakahara S, Akahani S, et al. (2003). Malignant transformation of thyroid follicular cells by galectin-3. Cancer Lett, 195(1),111-119.

63. Elad-Sfadia G, Haklai R, Balan E, Kloog Y. (2004). Galectin-3 augments K-Ras activation and triggers a Ras signal that attenuates ERK but not phosphoinositide 3-kinase activity. J Biol Chem, 279(33), 34922-34930.
64. Nakayama R, Kuroda J, Taniyama N, Yamamoto-Sugitani M, Wada S, Kiyota M, et al. (2014). Suppression of SERPINA1-albumin complex formation by galectin-3 overexpression leads to paracrine growth promotion of chronic myelogenous leukemia cells. Leuk Res, 38(1), 103-108.

65. Khaldoyanidi S, Glinsky V, Sikora L, Glinskii A, Mossine V, Quinn T, et al. (2003). MDA-MB-435 human breast carcinoma cell homo-and heterotypic adhesion under flow conditions is mediated in part by Thomsen-Friedenreich antigen- galectin-3 interactions. J Biol Chem, 278(6), 4127-4134.

66. Boscher C, Zheng Y, Lakshminarayan R, Johannes L, Dennis J, Foster L, et al. (2012). Galectin-3 protein regulates mobility of $\mathrm{N}$-cadherin and GM1 ganglioside at cell-cell junctions of mammary carcinoma cells. J Biol Chem, 287(39), 32940-32952.

67. Boscher C, Nabi I. (2013). Galectin-3-and phosphocaveolin-1-dependent outside-in integrin signaling mediates the EGF motogenic response in mammary cancer cells. Mol Biol Cell, 24(13), 2134-2145.

68. Zhang D, Chen Z-G, Liu S-H, Dong Z-Q, Dalin M, Bao S-S, et al. (2013). Galectin-3 gene silencing inhibits migration and invasion of human tongue cancer cells in vitro via downregulating b-catenin. Acta Pharmacol Sin, 34(1), 176-184.

69. Tsuboi K, Shimura T, Masuda N, Ide M, Tsutsumi S, Yamaguchi S, et al. (2007). Galectin-3 expression in colorectal cancer: relation to invasion and metastasis. Anticancer Res, 27(4B), 2289-2296.

70. Kim H, Lin H, Biliran H, Raz A. (1999). Cell cycle arrest and inhibition of anoikis by galectin-3 in human breast epithelial cells. Cancer Res, 59(16), 4148-4154.

71. Matarrese P, Tinari N, Semeraro M, Natoli C, Iacobelli S, Malorni W. (2000). Galectin-3 overexpression protects from cell damage and death by influencing mitochondrial homeostasis. FEBS Lett, 473(3), 311-315.

72. Takenaka Y, Fukumori T, Yoshii T, Oka N, Inohara H, Kim H-RC, et al. (2004). Nuclear export of phosphorylated galectin-3 regulates its antiapoptotic activity in response to chemotherapeutic drugs. Mol Cell Biol, 24(10), 4395-4406.

73. Nangia-Makker, Wang Y, Raz T, Tait L, Balan V, Hogan V, et al. (2010). Cleavage of galectin-3 by matrix metallo proteases in duces angiogenesis in breast cancer. Int J Cancer, 127(11), 2530-2541.

74. Shimura T, Takenaka Y, Tsutsumi S, Hogan V, Kikuchi A, Raz A. (2004). Galectin-3, a novel binding partner of betacatenin. Cancer Res, 64(18), 6363-6367.

75. Song S, Mazurek N, Liu C, Sun Y, Ding QQ, Liu K, et al. (2009). Galectin-3 mediates nuclear betacatenin accumulation and Wnt signaling in human colon cancer cells by regulation of glycogen synthase kinase3beta activity. Cancer Res, 69(4), 1343-1349.

76. Harazono Y, Kho DH, Balan V, Nakajima K, Zhang T, Hogan V, et al. (2014). Galectin-3 leads to attenuation of apoptosis through Bax heterodimerization in human thyroid carcinoma cells. Oncotarget, 5(20), 9992-10001. 
77. Cheng YL, Huang WC, Chen CL, Tsai CC, Wang CY, Chiu WH, et al. (2011). Increased galectin-3 facilitates leukemia cell survival from apoptotic stimuli. Biochem Biophys Res Commun, 412, 334-340.

78. Cheong TC, Shin JY, Chun KH. (2010). Silencing of galectin-3 changes the gene expression and augments the sensitivity of gastric cancer cells to chemotherapeutic agents. Cancer Sci, 101, 94-102.

79. Lee YK, Lin TH, Chang CF, Lo YL. (2013). Galectin-3 silencing inhibits epirubicin-induced ATP binding cassette transporters and activates the mitochondrial apoptosis pathway via $\beta$-catenin/GSK-3 $\beta$ modulation in colorectal carcinoma. PLoS One, 8(11), e82478.

80. Califice S, Castronovo V, Van Den Brule F. (2004). Galectin-3 and cancer. Int J Oncol, 25, 983-92.

81. Friedl P, Alexander S. (2011). Cancer invasion and the microenvironment: plasticity and reciprocity. Cell, 147(5), 992-1009.

82. Nangia-Makker P, Balan V, Raz A. (2008). Regulation of tumor progression by extracellular galectin-3. Cancer Microenviron, 1(1), 43-51.

83. Yu LG, Andrews N, Zhao Q, McKean D, Williams JF, Connor LJ, et al. (2007). Galectin-3 interaction with Thomsen-Friedenreich disaccharide on cancer associated MUC1 causes increased cancer cell endothelial adhesion. J Biol Chem, 282, 773-781.

84. Zhao Q, Guo X, Nash GB, Stone PC, Hilkens J, Rhodes JM, et al. (2009). Circulating galectin-3 promotes metastasis by modifying MUC1 localization on cancer cell surface. Cancer Res, 69, 6799-6806.

85. Zhao Q, Barclay M, Hilkens J, Guo X, Barrow H, Rhodes JM, et al. (2010). Interaction between circulating galectin-3 and cancer-associated MUC1 enhances tumor cell homotypic aggregation and prevents anoikis. Mol Cancer, 9:154.

86. Radosavljevic G, Jovanovic I, Majstorovic I, Mitrovic M, Lisnic V, Arsenijevic N, et al. (2011). Deletion of galectin-3 in the host attenuates metastasis of murine melanoma by modulating tumor adhesion and NK cell activity. Clin Exp Metastasis, 28(5), 451-462.

87. Dange MC, Srinivasan N, More SK, Bane SM, Upadhya A, Ingle AD, et al. (2014). Galectin-3 expressed on different lung compartments promotes organ specific metastasis by facilitating arrest, extravasation and organ colonization via high affinity ligands on melanoma cells. Clin Exp Metastasis, 31, 661-673.

88. More SK, Srinivasan N, Budnar S, Bane SM, Upadhya A, Thorat RA, et al. (2015). N-glycans and metastasis in galectin-3 transgenic mice, Biochemical and Biophysical Research Communications, 460, 302-307.

89. Markowska AI, Liu FT, Panjwani N. (2010). Galectin-3 is an important mediator of VEGF- and bFGF-mediated angiogenic response. J Exp Med, 207, 1981-1993.

90. Lindau D, Gielen P, Kroesen M, Wesseling P, Adema GJ. (2013). The immunosuppressive tumour network: myeloid-derived suppressor cells, regulatory $\mathrm{T}$ cells and natural killer T cells. Immunology, 138, 105-115.
91. Motz GT, Coukos G. (2013). Deciphering and reversing tumor immune suppression. Immunity, 39, 61-73.

92. Demotte N, Wieers G, VanDer Smissen P, Moser M, Schmidt C, Thielemans K, et al. (2010). A galectin-3 ligand corrects the impaired function of human CD4 and CD8 tumor-infiltrating lymphocytes and favors tumor rejection in mice. Cancer Res, 70, 7476-7488.

93. Chen HY, Fermin A, Vardhana S, Weng IC, Lo KF, Chang EY, et al. (2009). Galectin-3 negatively regulates TCR-mediated CD4+ T-cell activation at the immunological synapse. Proc Natl Acad Sci USA, 106, 14496-14501.

94. Fukumori T, Takenaka Y, Yoshii T, Kim HR, Hogan V, Inohara H, et al. (2003). CD29 and CD7 mediate galectin-3-induced type II T-cell apoptosis. Cancer Res, 63, 8302-8311.

95. Kouo T, Huang L, Pucsek AB, Cao M, Solt S, Armstrong T, et al. (2015). Galectin-3 Shapes Antitumor Immune Responses by Suppressing CD8+ T Cells via LAG-3 and Inhibiting Expansion of Plasmacytoid Dendritic Cells. Cancer Immunol Res, 3(4), 412-423.

96. Tsuboi S, Sutoh M, Hatakeyama S, Hiraoka N, Habuchi T, Horikawa Y, et al. (2011). A novel strategy for evasion of NK cell immunity by tumours expressing core 2 O-glycans. EMBO J, 30, 3173-3185.

97. Wang JM, Cheng YQ, Shi L, Ying RS, Wu XY, Li GY, et al. (2013). KLRG1 negatively regulates natural killer cell functions through the Akt pathway in individuals with chronic hepatitis $\mathrm{C}$ virus infection. J Virol, 87(21), 11626-11636.

98. Jiang HR, Al Rasebi Z, Mensah-Brown E, Shahin A, $\mathrm{Xu}$ D, Goodyear CS, et al. (2009). Galectin-3 deficiency reduces the severity of experimental autoimmune encephalomyelitis. J Immunol, 182, 1167-1173.

99. Fermino ML, Dias FC, Lopes CD, Souza MA, Cruz ÂK, Liu FT, et al. (2013). Galectin-3 negatively regulates the frequency and function of CD4(+) CD25(+) Foxp3(+) regulatory $\mathrm{T}$ cells and influences the course of Leishmania major infection. Eur J Immunol, 43(7), 1806-1817.

100. Orentas RJ, Kohler ME, Johnson BD. (2006). Suppression of anti-cancer immunity by regulatory $\mathrm{T}$ cells: back to the future. Semin Cancer Biol, 16, 137-149.

101. Ghiringhelli F, Menard C, Terme M, Flament C, Taieb J, Chaput N, et al. (2005). CD4+CD25+ regulatory $\mathrm{T}$ cells inhibit natural killer cell functions in a transforming growth factor-beta-dependent manner. J Exp Med, 202, 1075-1085.

102. Murugaiyan G, Saha B. (2009). Protumor vs antitumor functions of IL-17. J Immunol, 183(7), 4169-4175.

103. Ikeda H, Old LJ, Schreiber RD. (2002). The roles of IFN gamma in protection against tumor development and cancer immunoediting. Cytokine Growth Factor Rev, 13, 95-109.

104. Xu Z, Hurchla MA, Deng H, Uluckan O, Bu F, Berdy A, et al. (2009). Interferon-gamma targets cancer cells and osteoclasts to prevent tumor-associated bone loss and bone metastases. J Biol Chem, 284, 4658-4666. 
105. Mitra-Kaushik S, Harding J, Hess J, Schreiber R, Ratner L. (2004). Enhanced tumorigenesis in HTLV-1 tax-transgenic mice deficient in interferon-gamma. Blood, 104, 3305-3311.

106. Kakuta S, Tagawa Y, Shibata S, Nanno M, Iwakura Y. (2002). Inhibition of B16 melanoma experimental metastasis by interferon-gamma through direct inhibition of cell proliferation and activation of antitumour host mechanisms. Immunology, 105, 92-100.

107. Wu SY, Yu JS, Liu FT, Miaw SC, Wu-Hsieh BA. (2013). Galectin-3 negatively regulates dendritic cell production of IL-23/IL-17-axis cytokines in infection by Histoplasma capsulatum. J Immunol, 190, 3427-3437.
108. Fermin Lee A, Chen HY, Wan L, Wu SY, Yu JS, Huang AC, et al. (2013). Galectin-3 modulates th17 responses by regulating dendritic cell cytokines. Am J Pathol, 183, 1209-1222.

109. Newlaczyl AU, Yu L-G. (2011). Galectin-3 - A jackof-all-trades in cancer. Cancer Letters, 313, 123-128.

110. Song L, Tang J-W, Owusu L, Sun M-Z, Wu J, Zhang J. (2014). Galectin-3 in cancer. Clinica Chimica Acta, 431, 185-191.

111. Gabius HJ, Kayser K. (2014). Introduction to glycopathology: the concept, the tools and the perspectives. Diagn Pathol, 9:4. 